\title{
Murabaha İşlemlerinin Faizsiz Finans Muhasebe Standartlarına Göre Muhasebeleştirilmesinin TMS/TFRS'ler Açısından Karşılaştırmalı İncelemesi
} (Araştırma Makalesi)

In Terms Of TAS/TFRS Comparative Review of The Accounting of Murabaha
Transactions According to Interest Free Financing Accounting Standards Doi: 10.29023/alanyaakademik.834242

\section{Yavuz KILINÇ}

Arş. Gör. Dr., Kocaeli Üniversitesi, İ̈BF, İşletme Bölümü,

yavuzkilinc25@gmail.com

Orcid No:0000-0001-7545-8663

Bu makaleye atıfta bulunmak için: Kılınç, Y. (2021). "Murabaha İ̧slemlerinin Faizsiz Finans Muhasebe Standartlarına Göre Muhasebeleştirilmesinin TMS/TFRS'ler Açısından Karşılaşstırmalı İncelemesi”, Alanya Akademik Bakış, 5(3), Sayfa No.1213-1229.

\author{
Anahtar kelimeler: \\ Murabaha \\ Sözleşmeleri, İslami \\ Finansal Kuruluşlar, \\ TMS/TFRS, FFMS, \\ Katılım Bankacılığ \\ Makale Geliş Tarihi: \\ 01.12.2020 \\ Kabul Tarihi: \\ 23.08.2021
}

Keywords:

Murabaha Contract,

Islamic Financial

Institutions,

TAS/TFRS, IFAS,

Participation Bank

\section{ÖZET}

Murabaha sözleșmesi, peșin satın alma imkânı olmayan bir kişi/ișletmenin İslami Finansal Kuruluşlar (IFK) aracıllğg ile malı, vadeli olarak satın alma imkanı ortaya çıkaran sözleşme türüdür. Bu açıdan murabaha sözleşmesi bir satış sözleşmesi olarak karşımıza çıkar. Murabaha sözleşmelerinin geleneksel bankacılık sistemi içerisinde bir karşıllğ̆ bulunmamaktadır. Bunun yerine banka kişi/işletmenin ihtiyaç duyduğu ürünü satın alabilmesine yönelik kredi sağlayabilmektedir. Banka bu kredinin karşılı̆̆ olarak da belirli bir oranda faiz geliri elde edecektir. İslam dini faizi kesin olarak yasakladiğından tüketiciler, bankalardan bu yolla kredi elde etme yerine murabaha sözleşmeleri kapsamında satın almak istedikleri ürünü vadeli olarak satın alabilmektedirler. Çünkü İslami finansal kuruluşlarla yapılan murabaha sözleşmesi şeriat hükümlerine uygundur ve bu nedenle Müslümanlar tarafindan daha da kullanılabilir hale gelmektedir. Bu makalenin amacı, İslami Finansal Kuruluşlar tarafindan gerçekleştirilen murabaha işlemlerinin muhasebeleştirilmesine yönelik gerek TMS/TFRS'ler gerekse FFMS'lerin içeriğinin karşılaştırmalı olarak incelenmesidir.

\section{ABSTRACT}

The murabaha contract is a type of contract that enables a person / business purchase the goods in installments through Islamic Financial Institutions (IFIs) who cannot purchase it in advance. In this respect, the murabaha contract appears as a sales contract. Murabaha contracts have no equivalent in the traditional banking system. Instead, the bank can provide credit for the person / business to purchase the product they need. The bank is also receive interest income at a certain rate in exchange for this loan. Since the religion of Islam strictly prohibits interest, consumers can purchase the product they want to buy under murabaha contracts, instead of obtaining loans from banks in this way. Because the Murabaha contract made with Islamic financial institutions is is compatible with the provisions of Sharia and therefore 
murabaha contracts becomes even more available to Muslims. The purpose of this article is to comparatively examine the content of both TMS / TFRSs and IFAS for accounting of murabaha transactions carried out by Islamic Financial Institutions.

\section{GİRIŞ}

Gelişmekte olan bir endüstri olmasına karşılık uluslararası finansal piyasalarda İslami Finansal Kurumlar (İFK) en hızlı gelişen kurumlardır. İslami finans sektörü, sadece Müslüman ülkelerde değil Müslüman olmayan ülkelerde de faaliyet göstermekte, çeşitli finansal ürün ve hizmetler sunmaktadır. HCBS ve Citibank gibi uluslararası faaliyet gösteren bankalar, İslami finansın gelişen bu yönüne ayak uydurma adına kendi bankalarının İslami finans hizmeti sunan bankacılık birimlerini faaliyete geçirmiş durumdadırlar. (Ibrahim ve Ling, 2016:113) İFK'ların temel amacı yatırımcılarına geleneksel bankaların faizli sistemlerine karşılık İslam ilkelerine uygun helal kazanç sağlamalarına yönelik finansal hizmet sunmaktır. İktisadi yapısı, parayı ve malı değerlendirme biçimi ve ticari zihniyeti ile geleneksel bankacılık sisteminden ayrışan İFK'lar, İslami iktisadi yapıya uygun hareket edebilmesi için yeni sözleşme türleri ve yeni işlemler gerçekleştirmek durumundadır. (Cebeci, 2020:11) Bu açıdan düşünüldügünde modern murabaha, IFK'lar tarafından hayata geçirilen ve bu kuruluşların finansal sistem içerisindeki yerinin güçlenmesine katkı sağlayan başlıca finansman türleri arasında yer almaktadır.

Murabaha sözleşmesi, bir kredi alıp/verme işlemi olmayıp bir satış işlemidir. Modern murabaha, IFK'lar tarafından bir satış sözleşmesi ile vaadi alınan bir mal veya hizmetin satın alınarak müşteriye belirli bir kâr payı ile satılması olarak tanımlanabilir. Bu nedenle İFK tarafından müşteriye kredi tarzında belli bir miktar paranın sağlanarak müşteriye verilmesi söz konusu olmamaktadır. Çünkü İslam faizi ve gararı kesinlikle yasaklamıştır. Yaptıkları işlemler için Şeriat kurullarınca cevaz almaları gerekli olan İFK'lar da faiz ve garar unsuru içeren herhangi bir finansal işlemin var olması mümkün değildir. Bu da üzerinde yaşayanların büyük bir çoğunluğunun Müslüman olduğu Türkiye'de İFK'ların önemini daha da artırmaktadır.

IFK'lar Türkiye'de BDDK ve KGK hükümlerine tabi olarak işlemlerini yürütmektedirler. İşlemlerini KGK hükümlerine yönelik yapmaları İFK'ların TMS/TFRS'lere uygun muhasebe faaliyetlerini gerçekleştirmelerini zorunlu kılmaktadır. Ancak TMS/TFRS'lerin İFK'lar açısından uygun ve yeterli olmadığı görülmektedir. Bu nedenle bu kuruluşların uygulaması için FFMS'ler yayınlamıştır.

Bu çalışmada FFMS 28 Murabaha ve Diğer Vadeli Satışlar standardı açısından murabaha işleminin nasıl muhasebeleştirilmesi gerektiği sorusu ele alınmıştır. Ayrıca çalışmada FFMS'lerin düzenlemelerinin TMS/TFRS ile olan uyumu detaylı olarak incelenmiştir.

\section{2. İSLAMİ FINANSAL KURULUŞLAR AÇISINDAN MUHASEBE}

İslami finansal kuruluşların gelişmesi ve geleneksel muhasebe sistemlerinin temelini oluşturan varsayımların İslam inanç ve değerleri ile uyumlu olmadığı görüşünün artışı, İslami muhasebe araştırmalarının ve İslami şirket raporlarının gelişimine katkı sağlamıştır. (Velayutham, 2014:126)

İslami finansal kuruluşları diğer işletmelerden ayıran en temel özellik finansal raporlama da dâhil olmak üzere gerçekleştirilen tüm işlemlerde Şeriat kurallarına (İslam Hukuku) uygun hareket etmek zorunda olmalarıdır. (Ahmed vd., 2016: 192) Şeriat kelimesi "yol” veya "suyun kaynağına giden yol" anlamlarına gelen Arapça bir kelimedir. İslam bağlamında Şeriat 
insanları hem bu dünyada hem de ahrette mutluluğa götürecek açık ve dosdoğru yolu ifade eder. Şeriat ilkeleri de iki kaynaktan türemiştir. Bunlar; Kuran-1 Kerim ve Sünnettir. (Haniffa \& Hudaib, 2010:6)

İslami finansın temel ayırt edici özelliklerinden birisi gerçekleşen işlemlerde faizden kaçınmaktır. Bu nedenle İslami finansal araçların yasal yapıları ekonomik görünümde benzer olsalar dahi temelde faize dayalı finansal araçlardan farklıdırlar. Bundan dolayı İslami finansal araçların geçerliliğini sağlayabilmek için İslami ve Şeriat görüşlerine uygun muhasebe politikalarına ihtiyaç duyarlar. (Ahmed vd., 2016: 192)

İslam hukukunda ticaret ve finansa yönelik temel ilke, İlahi rehberlikle (Kuran, Sünnet, İcma ve Kıyas) açıkça yasaklananlar dışında ekonomik konularda hemen her şeye izin verilmiş olmasıdır. İslam hukuku kapsamında ticari ve finans alanında yasak olan şeyler genel itibari ile "Riba" ve "Garar" olarak sınıflandırılabilir. Kelime anlamı artmak/büyümek olan riba faiz ile ilişkilendirilse de faizden çok daha geniş bir içeriğe sahiptir. Ribanın yasaklanmasındaki temel nedenlerden birisi, eşit olmayan değerler üzerinden alışverişin yapılmış olmasıdır. Buna göre bir borç sadece nominal bedel üzerinden geri alınabilir, herhangi bir iskonto oranı kullanılamaz. Diğer bir yasak ise kelime anlamı ile tehlikeli/aldatmacalı anlamına gelen garardır. Garar gerçekleştirilen işlemlerde veya yapılan sözleşmelerdeki aşırı belirsizliği ifade eder. İslam hukuku mülkiyet ve zilyetliği birbirinden ayırır ve teslimatı sağlamak için bir malın satışından önce fiilen bulundurulması gereğini vurgular. Dolayısı ile satışa konu olan bir malın olmadığı durumda ve/veya alıcının/satıcının ticarete konu olan mal hakkında bilgisi olmadığında garar söz konusudur. Bu nedenle İslami bankaların varlıkları ve borçları riba ve garar içermeyen farklı türden finansal araçlardan oluşmaktadır. (Ahmed vd., 2019:870)

İslami finansal kurumlar için muhasebe, bir işletmenin paydaşlarına, İşletmenin sürekli olarak Şeriat sınırları dâhilinde ve sosyoekonomik hedefleri yerine getirmesini sağlayacak şekilde faaliyet gösterdiğine ilişkin bilgileri sağlayacak bir süreç olarak tanımlanabilir. Bu tanımlama İslami finansal kurumlar için muhasebe işlemlerinin sadece ekonomik boyutlarını değil aynı zamanda dini ve sosyal değerleri de göz önünde bulundurması gerektiğini ifade eder. (Ahmed vd., 2016: 192)

İslami muhasebe ile geleneksel muhasebe karşılaştırıldığında genellikle şu iki belirgin fark ortaya çıkmaktadır. Bunlar; (Ansari, 2018:46)

- İslam hukuku bilincine sahip paydaşların bilgi ihtiyaçları,

- Paranın zaman değeri göz önüne alındığında geleneksel finansal sistem ile tamamen zit olan işlemlerin yapısındaki farklılıklar nedeniyle ortaya çıkan muhasebe politikalarındaki farklılıklardır.

İslami muhasebe ile geleneksel muhasebenin karşılaştırmasından da görüleceği üzere, geleneksel muhasebeye karşılık İslami muhasebenin finansal ölçüm ve açıklama olmak üzere iki temel özelliğinin ön plana çıktığı görülür. İslami muhasebe literatürü finansal ölçüm araçlarının belirlenmesinde temel nokta olarak Zekatı dikkate almaktadır. Zekâtın finansal ölçüm noktasında temel alınmasının üç nedeni vardır. Bunlar; zekatın varlıkların ölçümü ile yakından ilgili olması, zekatın kuranda namazdan hemen sonra zikredilen ve İslam'ın temel şartlarından birisi olması ve ilk dönem Müslüman dünyasında muhasebe uygulamalarının zekat ile gelişmeye başladığına yönelik düşüncedir. Zekâtın finansal ölçüm araçları üzerindeki etkisi ise zekatın hesaplanmasında kullanılması gereken tekniklerden kaynaklanmaktadır. İslam 


\section{KILINÇ}

hukukçularına göre zekatın hesaplanmasında mal varlığının tarihi maliyeti değil o gün ki piyasa değeri dikkate alınmalıdır. Bu da finansal ölçüm aracı olarak geleneksel muhasebedeki tarihi maliyetin aksine cari maliyet yönteminin kullanımını gerektirir. Ayrıca finansal tabloların hazırlanmasında ihtiyatlılık kavramı yine geleneksel muhasebedeki işletme sahipleri üzerinde en az etki oluşturacak şekilde muhasebe politikalarının geliştirilmesini değil, topluma en çok etkiye sahip olacak yani zekatın daha fazla hesaplanmasını sağlayacak biçimde muhasebe politikalarının kullanımını gerektirir. Ayrıca yine geleneksel muhasebenin aksine İslami muhasebede işletmelerin finansal tablo dipnotlarında en azından şu bilgilerin raporlanması istenmektedir; İslam tarafından yasaklanan işlemlerin gerçekleştirilip gerçekleştirilmediği, ödenen ve ödenmesi gereken zekât yükümlülüğü ve gerek hayır kurumlarına gerekse çalışanlarına ve dahi çevrenin korunmasına yönelik yapılan faaliyetlerin açıklanmasıdır. Tüm bu açıklamalar, geleneksel muhasebe sistemine karşılık İslami muhasebede daha ayrıntılı açıklamaların yapılması gerektiğini gösterir. (İbrahim ve Yaya, 2005:86-89)

\section{MURABAHA FINANSMANI}

Murabaha finansmanı son zamanlarda İslami Bankacılık ürünlerinden en çok kullanılanı olarak karşımıza çıkmaktadır. Bu sebeple murabahanın özünde yer alan kredili veya vadeli alım-satım işleminin açıklanmasında yarar vardır.

Kredili alım satım işlemlerinde (Bey’u'l-müeccel) birkaç farklı alım satım türü karşımıza çıkar (Ayub, 2017:235). Bu alım satım türü üzerinde anlaşmaya varılan sözleşmenin türüne göre değişiklik arz eder. Satın alma işleminde malın bedelinin tespit edildiği yöntemler sözleşme türüne göre genel itibari ile aşağıdaki gibi sınıflandırılabilir (Ballail, 2019:19-20);

Müsâveme Sözleșmesi: İlgili tarafların üzerinde anlaştıkları mal ve bedelinin takasını ifade eder. Bu tür sözleşmelerde satıcı malı aldığı fiyatı genellikle saklı tutar.

Müzayede Sözleșmesi: Bu tür alış satış işlemlerinde satıcı malını pazara sunar ve alıcılardan gelen teklifler içerisinde en yüksek fiyatı verene malını satar.

Güvene Dayalı Satıș Sözleșmeleri: Güvene dayalı satış akitleri kendi içerisinde Tevliye Akdi, Murabaha Akdi ve Vedia Akdi olmak üzere üçe ayrılır.

a. Tevliye Akdi: Satıcının malı satın aldığı ilk fiyata herhangi bir ekleme ya da çıkarma yapmadan sattığg sözleşme türüdür.

b. Murabaha Sözleşmesi: Satıcının satın aldığı fiyata tarafların üzerinde anlaştığı belirli bir miktar kârın eklenerek satıldığı sözleşme türüdür.

c. Vedia Sözleşmeleri: Satıcının satın aldığ 1 ilk fiyat üzerinden belirli bir miktar indirime giderek yaptığı sözleşme türüdür. Burada satıcının zararı söz konudur.

Yukarıdaki sınıflandırmadan da görüleceği üzere İslami bankacılıkta çokça kullanımı ile karşımıza çıkan murabaha bir güvene dayalı satış sözleşmesi türüdür. Fakat İslami bankacılık tarafından günümüzde kullanılmakta olan murabaha usulü klasik manadaki murabaha usulünden farklıdır. Genel itibari ile modern murabaha önceden satın alma sözü veya herhangi bir finansal kuruluştan kredili mal edinmek isteyen kişinin başvurusu ile ortaya çıkar. Bu nedenle modern murabaha "satın alma siparişi üzerine murabaha" olarak adlandırılır. (Ayub, 2017:236) 
Murabaha kazanç, kâr ya da artış anlamına gelen "ribh" kelime kökünden türemiştir. Klasik anlamda murabaha sözleşmeleri malın satıcısının malın maliyetini açıkça belirtmesi ve malı alan ile üzerinde anlaştıkları kâr düzeyini tespit etmelerine dayalıdır. (Ayub, 2017:238) Klasik anlamda murabaha kavramı incelendiğinde satış işleminin vadeli veya peşin satış olması yönünde bir ayrımın gözetilmediği görülür. Çünkü klasik anlamda murabahada malın alıcısının ticari bilgilerden yoksun olması nedeniyle müsaveme türü işlemlere girişmek yerine esas amacı art niyetli satış işlemlerini ortadan kaldırmak olan maliyet artı kâr işlemi olarak da ifade edebileceğimiz murabahaya başvurmasıdır. (Ayub, 2017:238-242)

Bugünkü şekli ile modern murabaha, İslami bankacılık sisteminde bir sermaye işletim yönetimi ve bir yatırım finansman türüdür. Günümüzde murabaha, faizsiz bankacılık sisteminde uygulanan finansman modelleri içerisinde en çok uygulanan işlemdir. $\mathrm{Bu}$ da murabahanın faizsiz finans sisteminin omurgasını oluşturduğu anlamına gelir. (Cebeci, 2020: 34)

Modern murabaha, IFK'lar tarafindan kullanılan bir model olarak ilk defa 1976 yılında Mısır'da Sami Hasan Hammud tarafından ortaya atılmıştır. (Cebeci, 2020:20) Daha önce de değinildiği gibi murabaha İFK'ların en çok kullandığı ve yine İFK'ların gelişim sebepleri arasında olmasının bazı iktisadi nedenler bulunur. Bunlar; (Cebeci, 2020:46-48)

- Murabahanın kisa vadeli olmasi,

- Murabahanın hızlı para akışı sağlaması,

- Murabahanın nispeten daha düşük maliyetli bir işlem olması,

- Murabahada riskin asgari düzeyde olmas1,

- Murabahadaki belirlenebilirlik ve düzenlilik,

- Murabahanın geniş ölçekli olması,

- Murabahada iktisadi, idari ve kanuni açıdan uygulama ve kredi verme imkanının daha kolay olması olarak siralanabilir.

Şekil 1'de de görüleceği üzere, murabaha sözleşmesi ile peşin satın alma imkânı olmayan bir kişi/işletmenin katılım bankaları aracılığı ile malı vadeli satın alma imkanı ortaya çıkmaktadır. Şekil 1'den de tanımlanabileceği üzere murabaha sözleşmesi, İslami banka ile müşteri arasında yapılan ve kâra dayalı bir sözleşmedir. Burada müşteri İslami bankadan kendi adına satın almak istediği emtiayı peşinen satın almasını talep eder. Müşteri satın alınmasını istediği emtiayı daha sonra peşin satış bedeli ile birlikte önceden belirlenen bir kâr payını İslami bankaya geri öder. $\mathrm{Bu}$ ödeme tek seferde yapılabileceği gibi taksitler halinde de yapılabilir. Gerçekleşen bu murabaha işleminin İslam hukukuna uygun olabilmesi için, satın alma işleminin gerçek olması, kâr payı ve ödeme koşullarının önceden bilinmesi ve taraflarca kabul edilmesi gerekir. (Chelhi vd., 2017: 50)

Murabaha sürecinde, alımı ve satımı yapılacak olan malın İslam dinine göre helal sayılan mallardan olması ve ayrıca ilgili malın gerçekten kullanılması gerektiği konularına özellikle dikkat edilmelidir. Eğer bu şartlara dikkat edilmezse gerçekleşecek olan murabaha işlemi Şeriat hükümlerine uygun olmayacaktır. (Yüksel, 2016:180) En genel ifade ile İslami finansta murabaha sözleşmesi bir kredi verme işlemi olarak değil bir satış sözleşmesi olarak görür. $\mathrm{Bu}$ nedenle de finansal raporlarda "Krediler" hesap sınıfında değil "Alacaklar" hesap sinıfinda raporlanır. (Asker \& Yumuşak, 2020:133)

Murabaha sözleşmesinin belirgin özellikleri ise şöyle sıralanabilir; (Ansari, 2018: 128) 
- Murabaha işlemi maddi varlıklar ile bazı maddi olmayan varlıkların alım satımına konu edilebilir. Alacaklar da dâhil olmak üzere herhangi bir borçlanma aracına yönelik murabaha sözleşmesi yapılamaz.

- Bir satış işlemi olarak murabahaya konu olan varlıkların satışından önce satıcının mülkiyetinde olması ve alıcıya satmadan önceki mülkiyet risklerini üstlenmiş olması gerekir.

- Murabaha, diğer tüm satışlar gibi, fiyatın kesin olduğu teslimat zamanının ve ödemenin nasıl gerçekleştirileceğinin bilindiği, buna karşılık ertelenmesi durumunda ödemenin ne zaman yapılacağının belirtildiği ve taraflarca tüm şartların kabul edildiği bir satış sözleşmesidir.

- Bir murabaha işleminde vekil tayin edilmesi durumunda gerçekleştirilecek işlemler ayrı ayrı yapılmalı ve tüm işlemler belgelendirilmelidir.

- Sözleşmeye konu olan mal, İFK adına bir aracı (genellikle müşterinin kendisi) tarafından satın alınacağından, tedarikçi tarafından düzenlenen fatura genel olarak IFK adına olması gerekir.

- Geç ödeme veya temerrüt durumunda fiyat artımı yapılmaz veya cezai işlem uygulanmaz. Ancak müşterinin kasıtlı olarak borcunu ödememesinin önüne geçmek amacıyla sözleşmelerde kararlaştırılan ödemesiz dönem sona erdikten sonra ceza uygulanabilir. Cezai işlem, ancak müşterinin geçerli bir mazereti olmaksızın temerrüde düştüğü şüphesi kanıtlandığında verilebilir.

- Alıcının, yani müşterinin, varlık üzerinde rehin, ipotek, haciz veya başka herhangi bir takyidat şeklinde teminat sağlaması gerekebilir. Ancak, İslami bankanın bu tür bir teminattan herhangi bir finansal veya başka bir fayda elde etmesine izin verilmediğini belirtmek gerekir.

- Müşterinin halihazırda sahip olduğu mallarda geri alım düzenlemesi yasaktır. Bunlar bir Murabaha işleminde söz konusu olamaz. 


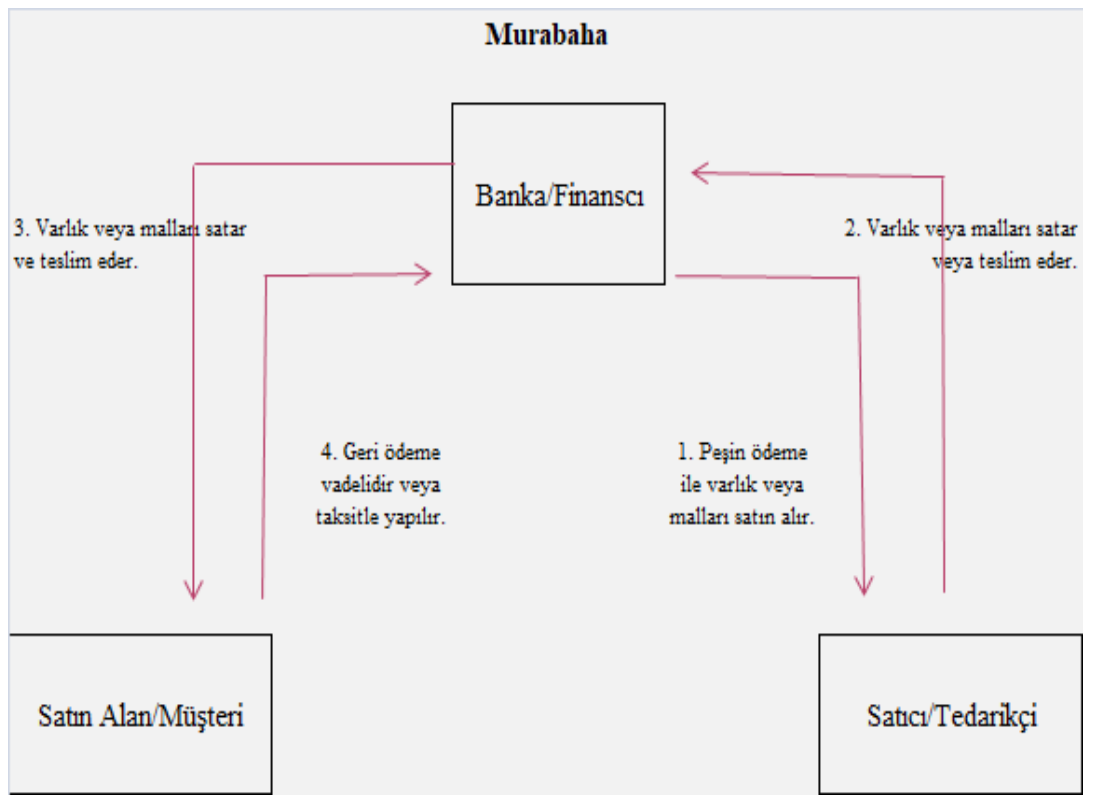

Şekil 1. Murabaha İşlem Süreci

Kaynak: Alrifai, 2017:190

\section{MUHASEBE STANDARTLARI VE İSLAMI FINANSAL KURUMLAR}

İslami bankacılık hizmeti veren kuruluşlar diğer geleneksel işletmeler gibi finansal rapor hazırladıkları, sundukları ve bu finansal raporları denetlettikleri gereği ile standartlara ihtiyaç duymaktadırlar. Bu nedenle geleneksel sistemde olduğu gibi faizsiz finansman hizmeti sunan kuruluşlar açısından da muhasebe standartları düzenleyen ve yayınlayan kuruluşlar bulunmaktadır. (Asker \& Yumuşak, 2020: 128)

Küreselleşen dünyada muhasebede uygulama birliği sağlamak adına yayınlanan ve uygulanan en yaygın muhasebe ilkeleri ve standartları seti Uluslararası Finansal Raporlama Standartları (UFRS)'dır. Bu raporlama standartları dünyanın çoğu ülkesi tarafından kabul edilmiş ve uygulanmaktadır. (Ansari, 2018) Bütün dünyada UFRS’ler, karşılaştırılabilirliği kolaylaştırmak ve şeffaflığı artırmak adına yaygın bir biçimde kullanılmaktadır. Ancak tüm faaliyet sektörleri açısından özellikle de İslami finans sektörü açısından yeterli olmadığı görüşü hakimdir. (Ibrahim \& Ling, 2016:114) İslami muhasebe açısından düşünüldüğünde UFRS'lerin önemli bir eksikliği göz önüne çıkmaktadır. Bu da İslam hukuku ilkelerine uygunluğun finansal raporlarda ifade edilmemesidir. Burada karşımıza çıkan temel soru şudur ki muhasebenin herhangi bir dinle ilişkisi olabilir mi? Bu sorunun cevabını farklı açılardan vermek mümkündür. Burada şu kadarını ifade etmek gerekir ki muhasebe işlemleri neticesinde İslam dinine tabi olan insanların ihtiyaçları rahatlıkla giderilebilir. Bu nedenle geleneksel muhasebe işlemlerine ek olarak, yapılan bu işlemlerin İslam hukuku ilkelerine uygun olup olmadığının finansal bilgi 


\section{KILINÇ}

kullanıcılarına aktarılması kişilerin önemli bilgi gereksinimlerini karşılamalarını sağlayacaktır. (Ansari, 2018)

İslami finans kuruluşlarının gerçekleştirdiği işlemlerin muhasebeleştirilmesine yönelik iki temel yaklaşımdan söz edilebilir. Bunlar; İslami muhasebe standartlarının yayınlanması ve uygulanması ve UFRS'lere gerekli ek açıklamalar oluşturarak IFK'lar için uyumlu hale getirmektir. Böyle bir ayrımın varlığı IFF'ların geleneksel işletmelerden farklı hüviyete ve işlemlere farklı bakış açılarına sahip olmalarından kaynaklanmaktadır. (Ansari, 2018:68) İslam hukukundan hareketle geliştirilen İslami bankacılık uygulamalarına yönelik kullanılacak muhasebe politikalarının tespitinde UFRS'ler kullanılamaz. Bunun nedeni bazı İslam hukuku ilkeleri ile UFRS'lerin uyumsuz olması ve bazı İslam hukukuna uygun gerekliliklerin UFRS'lerde yer almaması gösterilebilir. (Ahmed vd., 2019:867) Ayrica hemen hemen tüm dünyada kullanımı yaygın olan UFRS'lerde zekat hesaplamaları gibi bazı konularda açıklama gerekliliği görülmemiştir. Bu nedenle faizsiz finans kuruluşları küresel düzeyde kabul görecek İslami muhasebe standartları yayınlanması hususunda bir baskı ile karşı karşıya kalmışlardır. (Ajili \& Bouri, 2017:272) UFRS'lerin İslami finansal kurumlar açısından uygun olmadığından hareketle gönüllü olarak 1991 yılında Bahreyn'de kurulmuş olarak AAOIFI, İslami finansal kurumlar için muhasebe standartlarını yayınlamaya başlamıştır. (Ahmed vd., 2019:867)

AAOIFI'nin İslami finans kuruluşları için muhasebe ve denetim standartları yayınlamasına karşılık çoğu ülkede İslami bankaların uluslararası muhasebe standartlarına uygun raporlama yaptığı ve AAOIFI'nin yayınlamış olduğu standartlara uygun raporlama yapmayı "gönüllülük" esasına tabi tuttuğu görülmektedir. (Mohammed vd., 2015:419)

Türkiye'de 2012 y1lında kabul edilen Türk Ticaret Kanunu ile işletmeler UFRS'lerin tam metin çevirisi olarak yayınlanan ve kabul edilen Türkiye Muhasebe ve Finansal Raporlama Standartları (TMS/TFRS) uygulanmaları gerekmektedir. Bankalar ayrıca Bankacılık Düzenleme ve Denetleme Kurulu'nun düzenlemelerine de uymak zorundadırlar. Faizsiz bir bankacılık türü olan İslami bankalar da bu uygulamalara uymaları gerekmektedir. İslami finans kuruluşlarının TMS/TFRS'lere göre muhasebe işlemlerini gerçekleştirmeleri, İslami finans sektörünün bilgi kullanıcılarına kendilerini tam ve net biçimde ifade etmelerine ve yapılan işlemlerin İslami Şeriat kurallarına uygun gerçekleştirildiğine ilişkin bilgi verilmelerine imkan sağlamamaktadır. Ayrıca İslami finansal kuruluşların bilgi kullanıcıları, kamuoyuna açıklanmış, İFK'lara ait finansal raporları kıyaslamaları neticesinde İslami ürünlerin, yapılan yatırım türlerinin ve fon kaynaklarının neler olduğu hakkında yeterli bilgiye sahip olmamaktadırlar. Bu nedenle de tüm bu gerekliliklere uygun muhasebe düzenlemelerine ihtiyaç duymaktadırlar. AAOIFI ise tüm bu gereklilikleri karşılama gayesi ile hareket etmektedir. Fakat henüz Türkiye'deki hiçbir İFK, AAOIFI'nin muhasebe standartlarına uygun olarak finansal rapor düzenlediği ve denetimden geçirdiğini beyan etmemiştir. (Asker \& Yumuşak, 2020: 127)

\subsection{FFMS 28 Murabaha ve Diğer Vadeli Satışlar Standardı}

FFMS 28'in amacı gerek alıcı gerekse satıcı açısından murabaha ve diğer vadeli satışların finansal raporlarda gösterilmesine ve muhasebeleştirilmesine ilişkin esasları açıklamaktır. (FFMS md. 1)

Murabaha, satışa dayalı bir sözleşme türüdür. Bu sözleşme türünde üç taraf bulunur. Bunlar; İslami finansal kuruluş, alıcı ve satıcıdır. Belirli bir malı satın almak isteyen ve yeterli finansal desteği bulunmayan bir kişi/işletme, İslami finansal kuruluşa başvurarak malı kendi adına satın 
almasını ve kendisine üzerine belirli bir miktar kâr koyarak satmasını talep eder. Görüleceği üzere, murabaha sözleşmesinde iki önemli aşama bulunur. Bunlardan ilki müşterinin satın almak istediği malın IFK tarafından satın alınması ve müşteriye vadeli olarak satılmasıdır. Bu nedenle burada IFK'lar açısından geleneksel bankalar gibi kredi verme işlemi söz konusu olmayıp bir malın alım satımı söz konusudur. Bu da İFK'ların murabaha sözleşmesinde stoklar ve alacaklarının nasıl muhasebe ve raporlanması gereğini ortaya çıkarır. FFMS 28 Standardında bu konuya yönelik şu açıklamalar yer vermiştir.

\section{a. Murabaha Sözleşmesine Konu Olan Varlığın İlk Ediniminde Ölçülmesi}

Murabaha sözleşmesinin alıcı tarafını oluşturan müşterinin satın alınmasını istediği stoka yönelik kuruluşun stok üzerinde kontrole sahip olması durumunda finansal tablolara alınması gereğini ifade eder. Stoklar başlangıçta maliyet bedeli üzerinden gösterilir. Stok maliyeti, tüm satın alma maliyetlerini ve stokun mevcut konumuna ve durumuna getirilmesi için katlanılan diğer maliyetleri içerir. (FFMS 28, md. 5-6)

Stokların finansal tablolara alınması ve başlangıçta nasıl ölçüleceğine ilişkin TMS 2 stoklar standardı incelendiğinde FFMS 28'in benzeri bir açıklamanın yer aldığı görülür. Yani burada FFK'ların normal işletmelerin alım satım işlemine benzer bir işlem gerçekleştirilmesi gerektiği görülür. TMS 2 Stoklar standardında gerek üretim gerekse ticaret işletmelerine yönelik açıklamalara yer verilerek dönüştürme maliyetleri ile ilgili açıklamalara da yer verilmişken FFMS 28'de bu kadar detaylı açıklamalara yer verilmemiştir.

\section{b. Murabaha Sözleşmesine Konu Olan Varlığın Sonraki Ölçümü}

Stoklar, ilk kez finansal tablolara alındıktan sonra, maliyet değeri ile net gerçekleşebilir değerinden düşük olanı üzerinden ölçülür. Murabaha sözleşmesinin bağlayıcı vaadi olması ve müşterinin kredibilitesinin yeterli olması durumunda varlığı maliyet bedeline eşit veya maliyet bedelinden daha fazla tutarda almasının gerekli olduğu durumlarda satıcı, stokları varsa gerçeğe uygun değerindeki değişmelere bakmaksızın maliyet değeri üzerinden izler. (FFMS 28 md. 11 12) Burada satıcının stokları maliyet bedeli üzerinden izleyebilmesinin temel şartları murabaha sözleşmesinin alıcı konumunda olan kişi/işletmenin sözleşmeye konu varlığı satın alma vaadinin bulunması, maliyet bedelinden veya maliyetinden daha yüksek bir tutarda almasının gerekli olduğu durumların var olması gerekir.

Eğer yukarıda belirtilen şartlardan müşterinin kredibilitesinin yeterli olmasına rağmen murabaha sözleşmesine konu olan varlığı satın alma vaadinin bulunmaması durumunda ise satıcı net gerçekleşebilir değere indirgemek suretiyle (maliyet değerinden düşük olması durumunda) stokların defter değeri üzerinden düzeltmeler yapar. İndirgemenin karşılık etkisi finansal tablolara ilgili dönemde yansitılır. (FFMS 28, md. 13)

Geleneksel işletmelerde müşterinin vaadinin olup olması söz konusu değildir. İşletme satın aldığı malını maliyet değeri üzerinden finansal tablolarına almakta ve müşterisine satmaktadır. Burada satın alma vaadi olup olmaması ayrımı söz konusu değildir. Stokların sonraki ölçümüne bakıldığı zaman ise FFMS 28'de olduğu gibi stoklar maliyet ve net gerçekleşebilir değerden düşük olanı ile değerlendiği görülür. (TMS 2, md. 9) Stokları net gerçekleşebilir değere indirgeyen tutarlar ilgili dönemde finansal tablolara gider olarak yansitılır. (TMS 2, md. 34)

Yukarıdaki açıklamalardan da görüleceği üzere murabaha sözleşmesinin alıcı konumunda olan tarafın satın alma vaadinin olmadığı durumlar ile TMS 2 stoklar standardının benzer hükümler taşıdığı görülmektedir. 


\section{c. Alacakların Muhasebeleştirilmesi ve Finansal Tablolara Alınması}

İlgili stok murabaha veya başka bir vadeli satış sözleşmesi kapsamında satıldığında satıcı alacakları ve hâsılatı finansal tablolara yansıtır. Alacak itibari değer üzerinden değerlenir. (FFMS 28, md. 8-9) Brüt alacaklar, ilk kez finansal tablolara alındıktan sonra, ödenmemiş tutarlardan, varsa kredi zarar karşılıkları düşüldükten sonra kalan tutar üzerinden izlenir. Ödenmemiş tutar, alacakların brüt tutarından tahsilâtlar ve varsa izin verilen iskonto ve indirimler dâhil diğer düzeltmeler düşüldükten sonra kalan tutarı ifade eder. (FFMS 28, md. 15-16)

İtibari değer üzerinden ölçülen murabaha alacakları, varlığın müşteriye satış fiyatını temsil eder. Yani maliyetine eklenen kâr tutarını da içerir. (Rosman vd., 2016:8)

TMS/TFRS'ler açısından değerlendirildiğinde alacaklar finansal varlık olarak sınıflandırılır. İşletmeler açısından en temel finansal varlık, nakittir. Gelecekte sözleşmeden doğan nakit alma hakkını temsil eden veya nakit ödeme yükümlülüğünü gösteren finansal varlıklar; ticari alacak ve borçlar, alacak ve borç senetleri, kredi alacak ve borçları, alacak ve borç tahvilleri gösterilebilir. (TMS 32, paragraf UR3-4) $\mathrm{Bu}$ açıklamalardan da görüleceği üzere TMS/TFRS'ler alacakları finansal varlık olarak sınıflandırmaktadırlar.

Ticari alacaklar, işletmelerin esas faaliyetleri neticesinde ortaya çıkmaları nedeniyle TFRS 15 Müşteri Sözleşmelerinden Hâsılat standardı ile de ilişkilidir. (Gökgöz, 2019:167) TFRS 15 ise ticari alacaklara sözleşmede önemli bir finansman bileşeninin varlığının olup olmadığını göz önünde bulundurarak muhasebeleştirme ölçümü sunmaktadır. Önemli finansman bileşeninin varlığı, sözleşme taraflarınca ödemelerin zamanlaması, müşteriye veya işletmeye mal veya hizmetlerin müşteriye devrinin finansmanı şeklinde fayda sağlaması durumunda ortaya çıkar. Eğer önemli bir finansman işlevi barındırmıyorsa bu alacaklar işlem bedeli üzerinden muhasebeleştirilir. Ticari alacakların önemli bir fayda sağlaması durumunda, işletme işlem bedelini belirlerken taahhüt edilen bedelde paranın zaman değerinin etkisine göre düzeltme yapar. (TFRS 15, md. 61-63, TFRS 9, md. 5.1.3) Mal veya hizmetin devri ile ödeme zamanı arasında vade zamanının olması durumunun alıcı lehine önemli bir fayda sağlaması durumunda sözleşmenin önemli bir finansman unsuru taşıdığının göstergesi olarak kabul edilir. Aksi durumda önemli bir finansman unsuru taşımadığına hükmedilir. (Gökgöz, 2019:167-168) Ayrıca kolaylaştırıcı bir uygulama olarak, sözleşmenin başlangıcında mal veya hizmetin devri ile ödeme zamanının arasından bir yıldan daha kısa bir tarihin bulunması durumunda taahhüt edilen bedelde önemli bir finansman bileşeninin etkisi için düzeltme yapmak zorunda değildir. (TFRS 15, md. 63) Yani işletme ticari alacağı işlem bedeli üzerinden muhasebeleştirebilir.

Önemli finansman bileşenine sahip olmayan ticari alacaklar dışındaki finansal varlık ve yükümlülükler ilk defa muhasebeleştirilmelerinde gerçeğe uygun değer üzerinden muhasebeleştirilir. (TFRS 9, Md. 5.1.) İlk defa finansal tablolara alınan bir finansal varlık veya yükümlülük finansal tablolara alındıktan sonra ya itfa edilmiş maliyeti üzerinden ya gerçeğe uygun değer değişimi diğer kapsamlı gelire yansitılarak ya da gerçeğe uygun değeri kâr/zarara yansıtılarak ölçülür ve muhasebeleştirilir. Eğer bir finansal varlık, sözleşmeye bağlı nakit akışlarının tahsilini amaçlayan bir iş modeli kapsamında ve belirli tarihlerde sadece anapara ve anapara bakiyesinden kaynaklanan faiz ödemelerini içeren nakit akışlarına yol açması beklentisi mevcutsa ilgili finansal varlığı itfa edilmiş maliyet bedelinden ölçerek finansal tablolarına yansıtır. (TFRS 9, md. 4.1.1-4.1.2.) Bu da ticari alacakların itfa edilmiş maliyet bedelinden ölçülmesi gereğini ortaya çıkarır. İtfa edilmiş maliyet bedeli, Finansal varlık veya 
finansal yükümlülüğün ilk defa finansal tablolara alındığı tutardan, anapara geri ödemeleri düşüldükten sonra, bu tutara ilk defa finansal tablolara alındığındaki tutar ile vadesindeki tutar arasındaki fark üzerinden etkin faiz yöntemi kullanılarak hesaplanan toplam itfa tutarı eklenerek veya düşülerek bulunan tutardır. (TFRS 9 Ek A)

Gerek TMS/TFRS gerekse FFMS'nin ticari alacaklarla ilgili yaklaşımına bakıldığı zaman eğer alacağın vadesi bir yılın altında ise farklılık söz konusu olmayacaktır. Çünkü FFMS'de ticari alacakların itibari değer ile TFRS 9'da ise vadesi bir y1ldan az olan ve bünyesinde önemli finansman işlevi barındırmayan ticari alacakların işlem bedeli ile ölçülmesi gereği belirlenmiştir. Bu durum her iki değerinde eşit olmasını sağlayacaktır.

Uzun vadeli ticari alacakların ölçümüne yönelik ise TFRS 9, önemli finansman unsuru barındıran ve vadesinin bir yıldan daha uzun süreli olduğu ticari işlemlerden doğan alacağın itfa edilmiş maliyet değerinden değerlenmesi gerektiğini belirtmiştir. FFMS 28'de esasen alacakların sonraki ölçümüne yönelik uzun veya kısa vadeli bir ayrımın yapılmadığı görülmektedir. Ancak kârın ertelenmesi bölümünde vadesi 12 aydan uzun olan; taksitler hâlinde ya da vade sonunda defaten ödeme yapılacak işlemlerde, kârın zamana orantılı olarak itfa edilmesinde başvurulacak uygun yöntem, işlemdeki zımni kârı esas alan etkin kâr yöntemi olduğu belirtilmiştir. (FFMS, Md. 26) Bu madde gereğince uzun vadeli alacakların her iki standart açısından benzer nitelikte muhasebeleştirilmesi gereğinin ifade edildiği görülmektedir. Ancak TMS/TFRS'ler ticari alacakların ölçümünde sadece olayın ekonomik boyutunu dikkate almasına karşılık, FFMS'ler ekonomik faaliyetin İslam hukuku boyutunu da ele alarak değerlendirme yapmaktadır.

\section{d. Gelir ve Kâr Olarak Kaydetme}

Stokla ilgili risk ve getirilerin müşteriye devri gerçekleşmediği sürece gelir olarak kaydedilmez. Bu durum hem FFMS'ler hem de TMS/TFRS'ler açısından geçerlidir. (Ansari, 2018:130-131)

Vadeli murabaha veya diğer sözleşmelerde maliyet ve hâsılat arasındaki fark, ertelenmiş kâr hesabı aracılığı ile ertelenir. Ertelenmiş kâr hesabı alacakları düzenleyici bir varlık hesabı niteliğine sahiptir. Ertelenmiş kâr, sözleşmedeki kredi dönemi boyunca itfa edilerek gelirlere aktarilır. (FFMS 28, md. 23-25)

Ticari alacaklar kısmında da açıklandığı üzere TFRS 15'e göre bir müşterinin malı satın aldığ1 zaman ile ödeme yaptığı zamanın bir yıldan daha uzun süreli olması durumunda, sözleşmede önemli bir finansman bileşeninin varlığı kabul edilir ve hâsılatın muhasebeleştirilmesinde bu durum göz önüne alınır. Yani taahhüt edilen bedelden etkin faiz oranına göre paranın zaman değeri göz önünde bulundurularak yeniden değerleme yapılması gerekir.

Gerek FFMS gerekse TMS/TFRS açısından bakıldığı zaman her iki standart grubunun da benzer bakış açılarına sahip olduğu görülmektedir. Her iki standart da vadeden kaynaklı gelirin bir gelir unsuru olarak hâsılatta muhasebeleştirilmesini öngörmemektedir. Düzenleyiciler bu durumda işletmelerin hasılatın dışında "ertelenmiş kâr" veya "ertelenmiş vade farkı gelirleri" hesaplarını kullanmaları ve vadesi dolan bölümün etkin faiz oranı veya etkin kâr yöntemi kullanılarak gelir olarak kaydetmeleri gereğini ifade etmektedirler.

TMS/TFRS'ler ile FFMS'lerin Murabaha işlemine bakış açıları aşağıdaki tablo yardımı ile karşılaştırmalı olarak gösterilebilir: 
Tablo 1. Murabaha İșlemine Muhasebe Standartlarının Bakıs Açıları

\begin{tabular}{|c|c|c|c|}
\hline & FARKLILIKLAR & TMS/TFRS & FFMS \\
\hline 1 & $\begin{array}{l}\text { Raporlamada Esas } \\
\text { Alınan Standart }\end{array}$ & $\begin{array}{l}\text { Murabaha ile ilgili standart } \\
\text { yoktur. TFRS-15 Müşteri } \\
\text { Sözleşmelerinden Hasılat, TFRS } 9 \\
\text { Finansal Araçlar standartlarına } \\
\text { göre muhasebeleştirilir. }\end{array}$ & $\begin{array}{l}\text { Murabaha ve diğer vadeli işlemler, } \\
\text { FFMS } 28 \text { Murabaha ve Diğer Vadeli } \\
\text { Satışlar Standardı hükümlerine göre } \\
\text { muhasebeleştirilir. }\end{array}$ \\
\hline 2 & $\begin{array}{l}\text { Murabaha } \\
\text { İşlemlerinin } \\
\text { Raporlanmasına } \\
\text { Temel Teşkil Eden } \\
\text { Muhasebe Kavramı }\end{array}$ & Özün Önceliği Kavramı & $\begin{array}{l}\text { Özün önceliği ve işlemin hukuki } \\
\text { şekli birlikte dikkate alınır. }\end{array}$ \\
\hline 3 & $\begin{array}{l}\text { Murabaha } \\
\text { İşlemlerinin } \\
\text { Değerlendirilmesi }\end{array}$ & $\begin{array}{l}\text { Bir kredi işlemi olarak } \\
\text { değerlendirilir. }\end{array}$ & Bir satış İşlemi olarak değerlendirilir \\
\hline 4 & $\begin{array}{l}\text { Gecikmiş murabaha } \\
\text { alacakları üzerinden } \\
\text { alınan faizler }\end{array}$ & Faiz geliri olarak raporlanır. & $\begin{array}{l}\text { Katılım bankalarında faiz söz } \\
\text { konusu değildir. }\end{array}$ \\
\hline 5 & $\begin{array}{l}\text { Murabaha } \\
\text { alacaklarının } \\
\text { vadesinden önce } \\
\text { tahsil edilmesi }\end{array}$ & $\begin{array}{l}\text { Belirli bir oranda iskonto } \\
\text { uygulanır. }\end{array}$ & $\begin{array}{l}\text { İskonto uygulanmak zorunda } \\
\text { değildir. }\end{array}$ \\
\hline 6 & $\begin{array}{l}\text { Murabaha } \\
\text { İşlemlerinde İslami } \\
\text { Bankanın Rolü }\end{array}$ & $\begin{array}{l}\text { Banka murabaha konusu iktisadi } \\
\text { kıymetin alıcısı ile satıcıs1 } \\
\text { arasında finansal aracı } \\
\text { durumundadır. }\end{array}$ & $\begin{array}{l}\text { Banka bizzat ticari faaliyet } \\
\text { yapmaktadır. Murabaha konusu } \\
\text { iktisadi kıymeti satıcıdan satın alıp } \\
\text { alıcıya bizzat satmaktadır }\end{array}$ \\
\hline 7 & $\begin{array}{l}\text { Murabaha } \\
\text { İşlemlerinin Finansal } \\
\text { Durum Tablosunda } \\
\text { Sunulması }\end{array}$ & $\begin{array}{l}\text { Varlıklar Hesap Sınıfında Krediler } \\
\text { Başlığında Sunulmaktadır. }\end{array}$ & $\begin{array}{l}\text { Murabaha konusunu oluşturan varlık } \\
\text { Stok olarak görünür. Stok alıcıya } \\
\text { teslim edilince satılmış olduğu kabul } \\
\text { edilir. }\end{array}$ \\
\hline 8 & $\begin{array}{l}\text { Murabaha } \\
\text { İşlemlerinin Kar veya } \\
\text { Zarar Tablosunda } \\
\text { Sunulması }\end{array}$ & $\begin{array}{l}\text { Katılım Bankalarında Kâr Payı } \\
\text { Gelirleri hesap sınıfında } \\
\text { Kredilerden Alınan Kâr Payları } \\
\text { olarak sunulur. }\end{array}$ & $\begin{array}{l}\text { Murabaha satışları olarak } \\
\text { muhasebeleştirilir. Elde edilen kar } \\
\text { ise "ertelenmiş kar" kavramına } \\
\text { uygun olarak Kümülatif Ertlenmiş } \\
\text { Kâr Payı geliri olarak } \\
\text { muhasebeleştirilir. }\end{array}$ \\
\hline
\end{tabular}




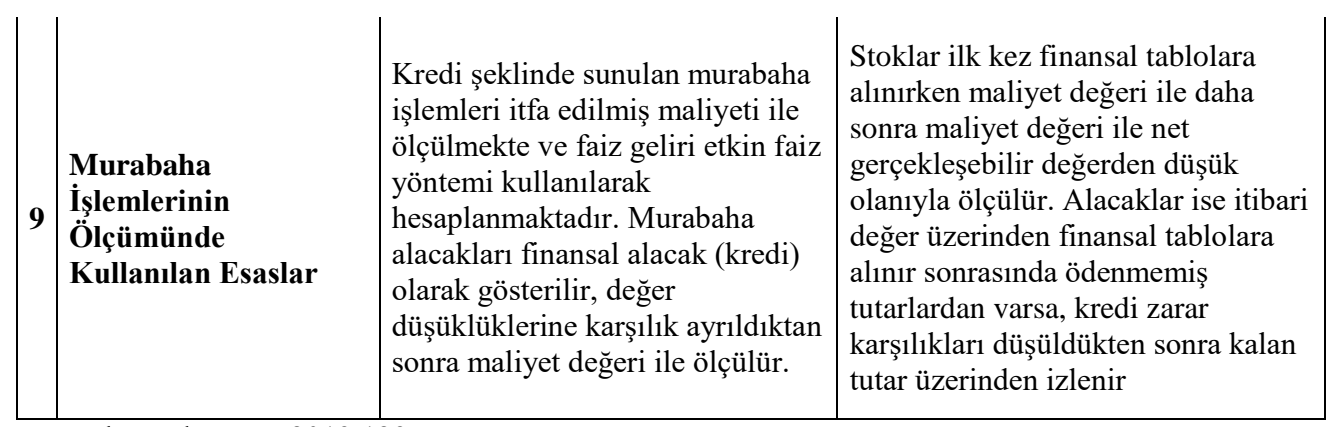

Kaynak: Aydoğmuş, 2019:129

Örnek Uygulama: Müşteri A 01.01.2020 tarihinde, peşin bedeli 1,000,000 TL olan bir varlığ1 satın alması için XYZ Katılım A.Ş. bankasına başvuru yapmış ve varlığı 18 ay vade ile satın alınması talebinde bulunmuştur. XYZ katılım bankası ilgili varlığı 18 ay vade ile 1,500,000 TL'ye müşteri A'ya varlığı satabileceğini belirtmiş ve taraflarca sözleşme imzalanmıştır. (KDV ihmal edilmiş olup, TCMB İskonto Oranının \%15 olduğu bilinmektedir.) Bu bilgilere göre gerekli muhasebeleştirme işlemini gerek TFRS'lere gerekse FFMS'ye göre muhasebeleştiriniz.

\section{TFRS 9 Kapsamında Muhasebeleştirme:}

Öncelikle burada TFRS'lere göre muhasebeleştirme yapılabilmesi için bu ticari faaliyetin normal bir ticari işlem olduğu ve var olan bir stokun müşteriye 18 ay vade ile satışının yapıldığı, ayrıca stokun maliyet bedeli ile finansal tablolara alındığı varsayımı gerekir. Bu varsayımdan hareketle şu açıklamalar yapılabilir;

- Stokun peşin satış fiyatı ile vadeli satış fiyatı arasında 500,000 TL fark bulunmaktadır.

- $\mathrm{Bu}$ fark TFRS 15'e göre önemli bir finansman unsuru barındıran sözleşmeden doğmaktadır. Bu nedenle hâsılat muhasebeleştirilirken paranın zaman değeri dikkate alınmalıdır.

- Ayrıca TFRS 9 gereğince ilgili alacağın itfa edilmiş maliyet bedeli üzerinden muhasebeleştirilmesi gerekecektir.

Satış Kaydı

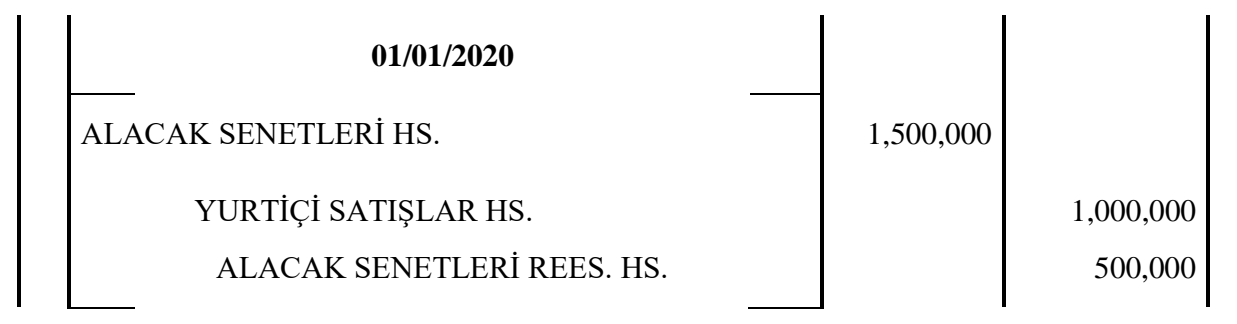

Satış kaydında görüleceği üzere alacak değeri işlem bedeli üzerinden değil, itfa edilmiş maliyet bedeli üzerinden ölçülmüştür. Çünkü satış işlemi alıcı lehine önemli bir finansman unsuru barındırmaktadır. Her ne kadar da alacak senetleri hesabında 1,500,000 TL olarak gösterilmiş olsa da bu değer alacak senetleri reeskontu hesabı ile bugünkü değere indirgenmiştir. Esasında bakıldığı zaman 500,000 TL bir finansman geliridir. Ancak bu gelir finansal tablolara 


\section{KILINÇ}

gerçekleştikçe aktarılması gerekir. İşletmenin yıllık finansal tablo düzenlediği varsayımından hareketle 31.12.2020 tarihinde yapması gereken muhasebe kaydı ise aşağıdaki gibi olacaktır:

$$
\begin{aligned}
& \text { Etkin Faiz Oranı }=(1,500,000 / 1,000,000)^{1 /\left(\frac{18}{12}\right)}-1=1.3104-1=0.3104 \\
& \qquad \begin{array}{c}
\text { Faiz Geliri }=\left(\frac{1,500,000}{1+0.3104}\right)^{\frac{6}{12}}=\frac{1,500,000}{1.144717}=1,310,367.54 \mathrm{TL}-1,000,000 \\
=310,367.54
\end{array}
\end{aligned}
$$

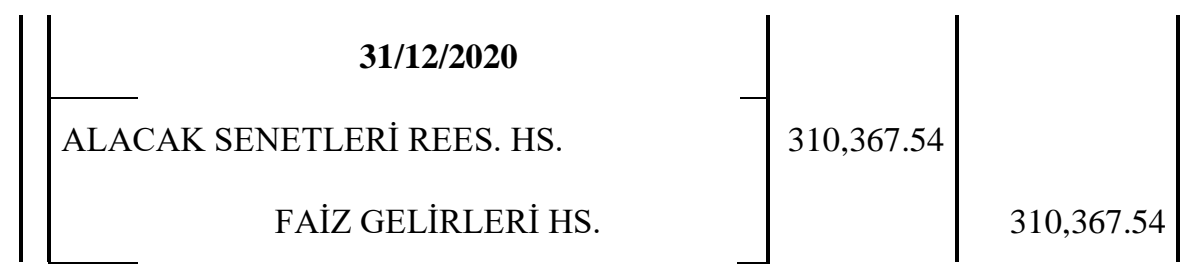

TFRS 15'e göre, yukarıda da görüleceği üzere bilanço tarihinde peşin değer ile alacağın itfa edilmiş maliyet değeri arasındaki fark artık bir gerçekleşen gelir olması nedeniyle faiz gelirleri hesabına aktarilır.

\section{FFMS 28'e göre Muhasebeleştirme}

Öncelikle burada katılım bankasının ilgili varlığı satın alarak maliyet bedeli ile finansal tablolarına alması gerekir. Bu işlem için aşağıdaki muhasebe kaydı yapılmalıdır:

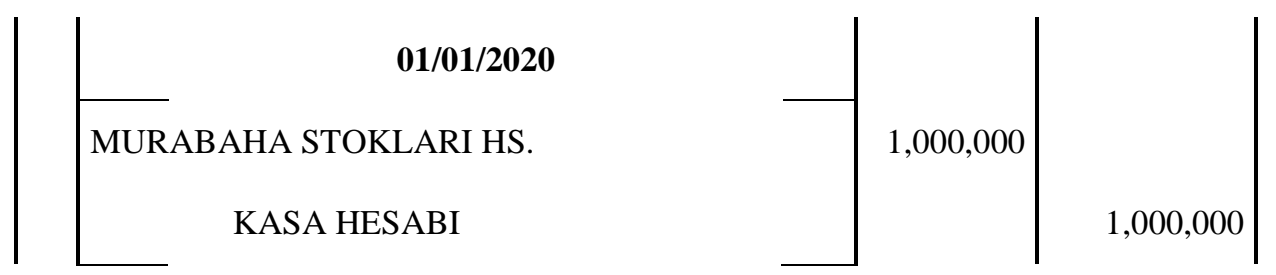

Sözleşme kapsamında malın satın alındıktan sonra müşteriye satışına yönelik yapılması gereken muhasebe kaydı ise aşağıdaki gibi olacaktır:

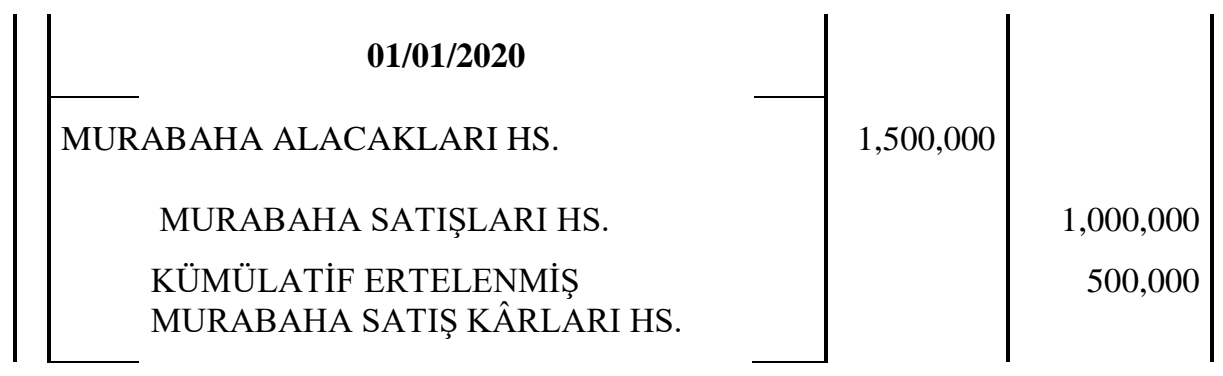



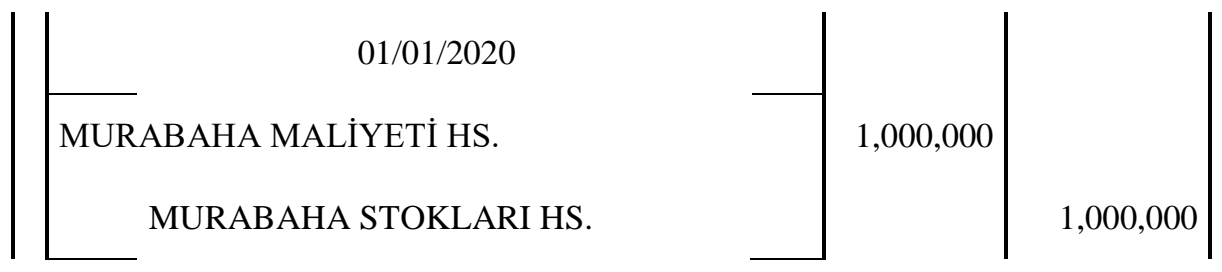

İlgili muhasebe kaydından da görüleceği üzere murabaha alacakları brüt alacak tutarından ilgili tahsilât, indirim ve iskontolar düşüldükten sonraki ödenmemiş tutar üzerinden gösterilmiştir. Yani alacaklar itibari değer üzerinden muhasebeleştirilmiştir. Sözleşmenin hayata geçirilmesi ile ilgili stok üzerindeki kontrolün alıcıya devredilmesi durumunda Murâbaha veya vadeli satış sözleşmesi kapsamında stokun satılmış olduğu kabul edilir. Stokların, satılması halinde, bu stokların defter değeri, katlanılan tüm doğrudan giderlerle birlikte, yukarıdaki muhasebe kaydında da görüleceği üzere ilgili hasılatın finansal tablolara alındığı dönemde satışların maliyeti olarak finansal tablolara alınır.

FFMS 28 madde 26 gereğince vadesi 12 aydan uzun olan işlemlerde, kârın zamana orantılı olarak itfa edilmesinde başvurulacak uygun yöntem, işlemdeki zımni kârı esas alan etkin kâr yöntemidir. Bu da kârın gerçekleştikçe finansal tablolara gelir olarak yansıtılması, gelirin hesaplanmasında da etkin kâr yönteminin uygulanması gerektiğini belirtir. Bu açıdan düşünüldüğünde finansal durum tablosu düzenlenme tarihinde etkin kâr yöntemine göre hesaplanan kâr rakamı gelir olarak muhasebeleștirilmesi gerekir. İlgili muhasebe kaydı aşağıdaki gibidir: ${ }^{1}$

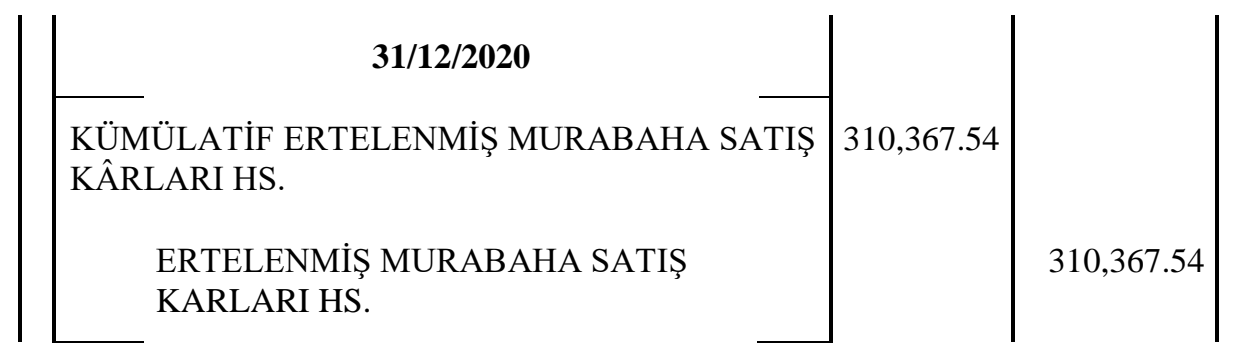

Yukarıdaki örnek uygulamadan da görüleceği üzere TFRS'ler ve FFMS arasında belirgin benzerlikler bulunmaktadır.

Gerçekleşen işlemin 12 aydan uzun olmamıs olması durumunda ise TFRS'lere göre önemli bir finansman unsuru barındırmadığı veya kolaylaştırıcı işlem olması hasebiyle alacakların üzerindeki paranın zaman değerini dikkate almaya gereksinim bulunmayacaktır. Ayrıca FFMS'lere göre ise vadesi 12 ay veya daha kısa olan, vade sonunda topluca ödenecek işlemlerde, kârın sözleşmedeki kredi dönemi boyunca doğrusal olarak dağıtımına izin verilir. (FFMS, 28, md. 27) Yani burada ortaya çıkacak olan kâr paylarının aylara eşit olarak

\footnotetext{
${ }^{1}$ Etkin kâr yönteminin etkin faiz oranı yöntemi ile aynı olduğu kanaatinden hareketle ayrıca hesaplama yapılmamıştır.
} 


\section{KILINÇ}

dağıtılarak kâr olarak yazılabileceği belirtilmektedir. Bu durumda yıllık finansal tablo düzenleyen bir işletme açısından işlemin gerçekleştiği zaman, ilgili yıla düşen kâr tutarının ertelenmiş kâr uygulamasına başvurmadan doğrudan kâr olarak yazılabileceği anlamını taşımaktadır.

\section{SONUÇ VE TARTIŞMA}

Genel itibari ile bakıldığı zaman hem TMS/TFRS'ler hem de FFMS'ler, finansal tablo bilgi kullanıcılarına önemli ve yararlı olacağı düşünülen finansal bilgilerin şeffaf ve gerçeğe uygun sunumunu ve açıklamasını sağlamayı hedeflemektedir. FFMS'lerin finansal bilgileri şeffaf ve gerçeğe uygun sunma ve açıklama çabası, İslami finansal kuruluşların bilgi kullanıcılarına şeriat yani İslam hukuk gerekliliklerine uygun hareket edildiğine yönelik özel sunum ve açıklamaları paydaşların ihtiyaçlarını giderme ve hesap verme sorumluluklarını karşılaması içindir. (Rosman vd., 2016:9) Ancak ele alınan bu çalışmada da görüleceği üzere İslami finansal kuruluşlar için önemli bir finansal enstrüman olan murabaha açısından TMS/TFRS'lerde herhangi bir açıklama bulunmamaktadır. Daha doğrusu TMS/TFRS'ler IFK'lar için uygun bir raporlama diline de sahip değildir. Çünkü IFK'lar faiz ve garar konusunda önemli İslam hukuku ilkelerini gözetmek ve gerçekleştirilen işlemlerde İslami cevaza sahip olmaları gerekmektedir. Ancak TMS/TFRS'ler herhangi bir dini veya dinin emir ve yasaklarını dikkate almadan hazırlanmış bulunmaktadır. Çalışmada da değinildiği üzere bu durum IFK'lar açısından İslami hukuk kurallarını dikkate alan muhasebe standartlarının geliştirilmesi için ön ayak olmuştur. AAOIFI tarafından geliştirilen bu standartlar Türkiye'de Faizsiz Finansman Muhasebe Standartları olarak yayımlanmıştır. Çalışmada konu olarak ele alınan murabaha sözleşmelerine yönelik 28 numaralı standart yayımlanmış ve TMS/TFRS'ler ile bu standardın karşılaştırılması yapılmıştır. Özellikle İslami hukuk kurallarını dikkate alarak hazırlanan bu standartların, TMS/TFRS'lerce hazırlanan standartlara göre daha sade oldukları ve çokça ayrıntıya girmedikleri görülmektedir. Ancak bu standartların ayrıntıya girmemiş olması onların faydasız olacağı anlamına gelmemektedir. İslami finansal kuruluşlar için bilgi ihtiyacı hisseden taraflara gereken önemli finansal bilgilerin açıkça sunumu bu standartlarca sağlanabilmektedir. Murabaha işlemi açısından düşünüldüğünde niteliği farklı olsa da her iki düzenleme de benzerliklerin olduğu açıkça görülmektedir.

\section{KAYNAKÇA}

AHMED, M. U., SABIRZYANOV, R., \& ROSMAN, R. (2016). “A critique on accounting for murabaha contract: A comparative analysis of IFRS and AAOIFI accounting standards". Journal of Islamic Accounting and Business Research, Vol. 7 No. 3, 190-201.

AHMED, H., ARIFFIN, F. A. T., KARBHARI, Y., \& SHAFII, Z. (2019). “Diverse accounting standards on disclosures of Islamic financial transactions Prospects and challenges of narrowing gaps”. Accounting, Auditing \& Accountability Journal, Vol. 32 No. 3, 866896.

AJILI, H., \& BOURI, A. (2017). "Comparative study between IFRS and AAOIFI disclosure compliance Evidence from Islamic banks in Gulf Co-operation Council countries". Journal of Financial Reporting and Accounting, Vol. 15, No. 3, 269-292.

ALRIFAI, T. (2017). İslami Finans ve Yeni Finansal Sistem: Gelecekteki Finansal Krizlerden Korunmak İçin Ahlaki Bir Yaklaşım, Ankara: Buzdağı Yayınları. 
ANSARI, O. M. (2018). IFRS and the Shari'ah Based Reporting A Conceptual Study. www.aaoifi.com [13.11.2020].

ASKER, E., \& YUMUŞAK, İ.G. (2020). "Katılım Bankalarının AAOIFI Standartlarına Uygun Finansal Raporlama Uygulamaları”. Íslam Ekonomisi ve Finansı Dergisi, 6(1) 125-142.

AYDOĞMUŞ, T. (2019). Murabaha İşlemlerinin TFRS ve İslami Finansal Kuruluşlar Muhasebe Standartları Kapsamında Değerlendirilmesi: Albaraka Türk Örneği, Sivas Cumhuriyet Üniversitesi, Sosyal Bilimler Enstitüsü, Yayımlanmamış Yüksek Lisans Tezi.

AYUB, M. (2007). Understanding Islamic Finance. England: John Wiley \& Sons Ltd.

BALLAIL, H. A. A. (2019). İslam Hukukunda Taksitli Satış, Kastamonu Üniversitesi, Sosyal Bilimler Enstitüsü, Yayımlanmamış Yüksek Lisans Tezi.

CEBECI, İ. (2020). İslam İktisadında Murabaha: Modern Literatürdeki Tartışmalar, Ankara: İktisat Yayınları.

CHElHi, K., HACHLOUfi, M., ABOUlethaR, M., EDDAOUI, A., \& MARZAK, A. (2017). "Estimation of Murabaha Margin", Journal of Applied Finance \& Banking, vol. 7, no. 5, 49-61.

FFMS 28 Murâbaha ve Diğer Vadeli Satışlar Standard1

GÖKGÖZ, A. (2019). "TFRS 9 Finansal Araçlar Standardı Çerçevesinde Ticari Alacaklara İlişkin Beklenen Kredi Zararlarının Tespiti ve Muhasebeleştirilmesi”. Journal of Accounting, Finance and Auditing Studies, Vol 5, No 2, 163-178.

HANIFFA, R., \& HUDAIB, M. (2010). "The two Ws of Islamic accounting research", Journal of Islamic Accounting and Business Research, Vol 1, No 1, 5-9.

IBRAHIM, S.H.M., \& YAYA, R. (2005). "The Emerging Issues on the Objectives and Characteristics Of Islamic Accounting For Islamic Business Organizations”, Malaysian Accounting Review, Volume 4 No. 1, 75-92.

IBRAHIM, H.D., \& LING, D.X. (2016). “An appraisal of the financial reporting practices of Islamic banks: the case of Murabahah contract", Scientific Journal of PPI-UKM, Vol. 3, No. 3, 113-118.

MOHAMMED, N.F., FAHMI, F.M., \& AHMAD, A.E. (2015). "The influence of AAOIFI Accounting Standards in Reporting Islamic Financial Institutions in Malaysia", International Accounting and Business Conference, 418-424.

ROSMAN, R., HAMID, M., AMIN, S. N., \& AHMED, M. U. (2016). "Financial Reporting of Murabaha Contracts: IFRS or AAOIFI Accounting Standards?" Middle East Insights Islamic Finance Special Middle East Institute, National University of Singapore, 1-14.

TFRS 9 Finansal Araçlar Standard 1

TFRS 15 Müşteri Sözleşmelerinden Hasılat Standard1

TMS 2 Stoklar Standard1

TMS 32 Finansal Araçlar: Sunum Standard1 
KILINÇ

VELAYUTHAM, S. (2014). "Conventional Accounting vs Islamic Accounting: the debate revisited". Journal of Islamic Accounting and Business Research, Vol. 5 No. 2, 126141.

YÜKSEL, S. (2016). İslam ekonomisi ve finansı. İçinde S. Erdoğan, A. Gedikli ve D. Çağrı Yıldırım (Ed.) İslami bankacılığı ortaya çıkaran nedenler ve İslami bankacılığın finansal istikrara katkıları. (ss. 153-174) İzmit: Umuttepe Yayınları. 